\title{
Konsten att se - Bröderna Hesselius möte med indianer i östra Nordamerika
}

\section{Av Gunlög Fur, universitetslektor i historia}

\author{
Länk till presentation av Gunlög Fur
}

Vad ser man då när man kommer till en ny plats? Vad är det som avgör vad man noterar? Varför tycks en del människor "se" medan andra framstår som blinda trots att de alla kommer med intakta synnerver?

När européerna kom till den amerikanska kontinenten förekom ofta uttalanden om att de kommit till ett tomt och öde land. William Bradford, guvernör för den puritanska Plymouth-kolonien, får stå som exempel i det han skrev om landet som togs över av kolonien:

\begin{abstract}
...dessa vidsträckta \& obebodda länder i Amerika, vilka är fruktbara \& lämpliga för bosättning, eftersom de är tomma på alla civiliserade invånare, där finns endast vilda \& barbariska människor, vilka rör sig upp och ned i landet, inte olikt de vilda djuren.
\end{abstract}

Mycket kunde sägas om Bradfords citat, men här räcker det att konstatera att hans beskrivning i alla delar är inkorrekt, men att han inte på något sätt var ensam om sina intryck av den nya världen.

För en historiker är vad vi ser naturligtvis inte en fråga om biologiska funktioner utan handlar om ett slags kulturellt djupseende, eller kulturell flerspråkighet. En mängd studier har publicerats som på olika sätt analyserar de europeiska kulturella begränsningar och föreställningar som bidrog till de beskrivningar som gjordes av mötet med andra folk. I dessa har man konstaterat hur européer konstruerade "bilder" av andra folk och hur dessa konstruktioner kunde styra det man "såg". Mer sällan har man behandlat exemplen på de som avvek från denna syn. Jag vill här göra ett försök att förklara kulturellt flerdimensionellt seende utifrån två svenska bröders vistelse i östra Nordamerika under första delen av 1700-talet.

Väldoftande träd i sin ymnigaste vårblomning "at wij tyckte [oss] då wara komne uti ett Paradis" och fåglars sång så ljuvlig "at ingen Musiqve kunde behageligare vara" mötte bröderna Andreas och Gustaf Hesselius då de den 23 april 1712 för första gången steg i land i norra Amerika. Andreas förtjusning över naturens fägring var säkert färgad av den långa och bitvis strapatsrika resa över Atlanten som nu äntligen ändats, men den entusiasm och nyfikenhet som präglade hans första möte med det nya landet kom att bli ett kännetecken i alla hans senare brev och anteckningar. Vid denna första promenad på Marylandskusten råkade bröderna också "i en apelskog twänne Indianer, nästan hel nakne, hafwandes allenast en wepa öfwer axlarne". Andreas och Gustaf blev häpna vid åsynen av dessa, men indianerna hälsade hövligt på dem med ett "Haita, thet är ett hälsningsord, som swarar emot wårt God dag" innan de hastade vidare. Dessa okända och oklädda vildar visade sig alltså bete sig på ett begripligt sätt och hälsningsordet kontrasterar mot beskrivningen av nakenhet och brun hud på ett sätt som föregriper bröderna Hesselius' senare kontakter med landets indianska invånare.

Bröderna Hesselius hade fint påbrå. Deras mor, Maria Bergius, var syster till Skarabiskopen Jesper Swedbergs andra hustru och Andreas tycks ha varit något av sin morbrors favorit. Född år 1677 utbildades han i Uppsala och 1711 kallades han, på Swedbergs anmodan, till präst i de svenska församlingarna i Amerika. Han stannade sen i Pennsylvanien till 1722 och slutade sina dagar som kyrkoherde i Gagnef. Brodern Gustaf föddes 1682 och skrevs även han in vid universitetet och lämnade Uppsala med titeln "conterfejare". Det är osäkert varför han följde med sin bror på Amerika-resan, men vi vet att han 1740 fick medborgarrätt i Pennsylvanien och att han dog i sitt hem i Philadelphia år 1755. Gustaf blev under sin levnad känd som porträttmålare, om än Pennsylvaniens elit tycks ha hyst vissa reservationer då hans målningar inte dolde skavanker och skönhetsfel. Han var också road av musik och tillverkade 1746 den första kyrkorgeln i Amerika till den moraviska församlingen - herrnhutare - i Bethlehem som ligger ca. 10 mil norr om Philadelphia. Båda bröderna gifte sig ganska omgående, Andreas först med holländskan Sarah 
Wallrave, sen Gustaf med engelskan Lydia Getchie.

Gustaf kom att röra sig i Philadelphias högre cirklar. Det är i kraft av dessa kontakter som hans namn kommit att förknippas med de ursprungliga invånarna i Pennsylvanien, lenapeindianerna. 1735 fick Gustaf Hesselius en beställning av familjen Penn att porträttera två av de lenapiska huvudförhandlarna vid det som kom att kallas "the Walking Purchase", då bröderna Penn i en mycket kontroversiell affär lurade lenaperna på ett stort landområde. Denna beställning resulterade i de två kanske märkligaste indianporträtt som finns från Amerikas kolonialtid. De lenapiska ledarna Lappawinzo och Tishcohan visas realistiskt avbildade på ett sätt som skarpt kontrasterar mot de symbolladdade bilder som annars producerades av indianer. Deras mänsklighet och värdighet framstår klart och deras individualitet har inte fått ge vika för schablonföreställningar om indianer. De attribut med vilka de är avbildade hör naturligt till deras utstyrsel och är inte ditplacerade.

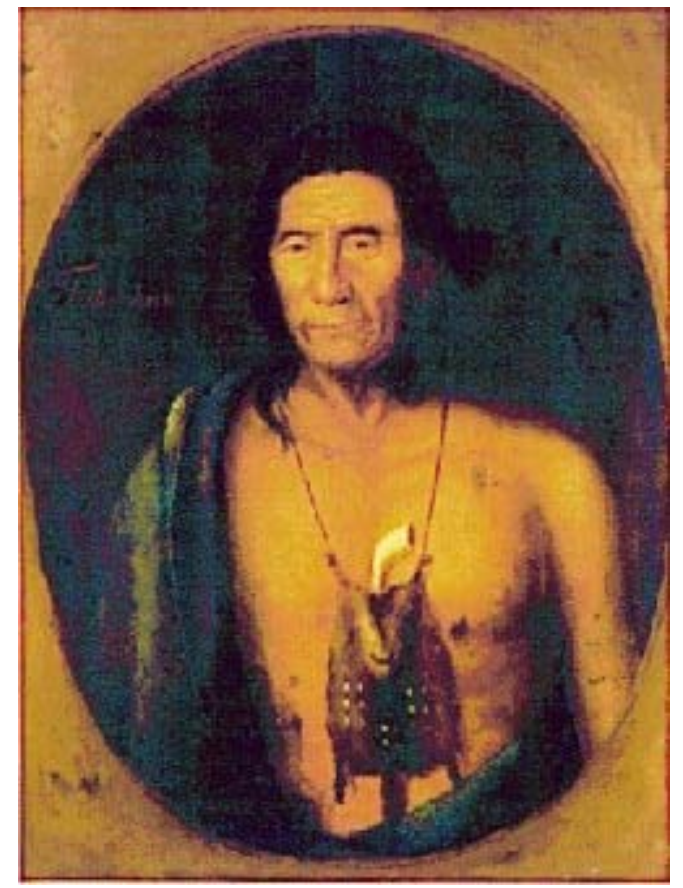

Lenapehövdingen Tishcohan

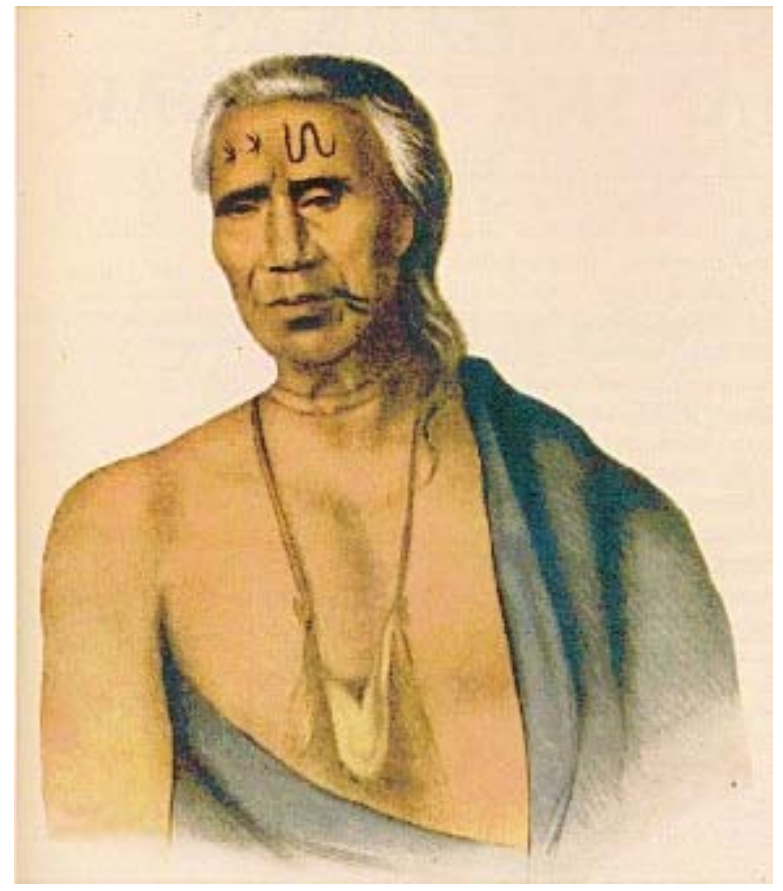

Lenapehövdingen Lappawinzo

Lappawinzo framträdde vid förhandlingarna 1735 som lenapernas främste talare. I indiansk diplomatisk kultur företräddes indianerna av talare som speciellt tränat sig att använda retoriken i syfte att på ett korrekt sätt förmedla ord och de relationer som var kopplade till orden. Talaren var själv inte utsedd till sachem (hövding i europeiskt språkbruk) utan företrädde denne/dessa. Lappawinzo framträdde senare vid flera tillfällen och utryckte sin vrede och missnöje med det ohederliga "köpet" av land. Han torde ha varit i fyrtioårsåldern då porträttet målades och levde sedan till hög ålder. Tishcohan var en av de fyra sachems som undertecknade det slutgiltiga avtalet med bröderna Penn år 1737. Han var troligen sachem i den by som också Lappawinzo bodde i. Tillsammans med sitt folk flyttade Tishcohan på 1740-talet västerut undan vit bosättning och landspekulation.

Vad förmår en man som rör sig i Philadelphias yppersta kretsar att göra sådana ingående och medkännande porträtt av två indianer? Var porträtten Hesselius protest mot en politik som berövade lenaperna stora delar av deras ursprungliga land? Själv har Hesselius inte lämnat många ledtrådar. I det enda brev som finns bevarat från honom skriver han 1714 till sin mor att

hwad Indianerna anbelangar så är det ett grufwligit och faseligit folck...Alla gå nakne och lefwa wärre än Swijn. Jag har ock warit i deras stad...De bygga sina huus av barck och wilja giärna fägna oss; gifwa oss äta och dricka, men Gud beware oss ifrån deras mat. Ibland äta de folckkiött när de dräpa hwarandra.

Detta låter förvisso inte som en man som förmår se bortom de yttre attributen i en annan kultur. Men detta 
skrevs i början av hans liv i Amerika och under årens gång visar Hesselius handlingar att han inte hade någon självklar kulturell hemvist i det nya landet. Han övergick, kanske under inflytande av sin hustru, till den anglikanska kyrkan, men under orgelbygget i Bethlehem fångades han av den moraviska förkunnelsen och blev medlem i den herrnhutiska församlingen vars främsta uppgift i Nordamerika var att missionera bland indianer. Men inte heller här tycks han ha känt sig hemma utan återgick i slutet av sitt liv till den lutheranska tro i vilken han uppfostrats. Kanske måste vi gå till hans bror Andreas och den miljö i vilken han verkade för att hitta förklaringar.

Den äldre brodern Hesselius kände sig mer hemma i skogen än i predikstolen och hans tålamod i naturiakttagelser och jakt kontrasterar skarpt mot hans otålighet och bryskhet gentemot de församlingsmedlemmar han säger lever "helt plumpt och incivilt". Det är med uppenbar glädje och nyfikenhet som Hesselius beskriver allt det nya han upplever i naturen och bland ursprungsinvånarna. Han är lyrisk i sin beskrivning av kolibrin som har "en obeskrifwelig skiön fläck, hwilcken glantzar, som ett glimmande Eldkohl, och är af en så liflig och lika som gnistrande rodna, som iag är säker, at han af ingen Målare kan med någon så hög färg afskildras". Han njuter av landets frukter och bär, roar sig med den nödvändiga jakten. Under sina långa vandringar i skog och mark måste han ha råkat många indianer för han nämner ofta om indianska namn och seder och till skillnad från den stadsboende brodern Gustaf har han ingen avsky för den indianska maten. Tvärtom skriver han t ex om landsköldpaddan som äts av både "Indianer och Christna\&" att "efter indianska tillredningen smakar hon bäst". Han lär sig snart att i kontakterna med indianerna ges kunskaper som i allt är nödvändiga för överlevnaden. Tydligast blir detta när hans tvåårige son blir allvarligt sjuk med mask. "En hederlig Indianska Chicalicka Nanni Kettelev benämnd" räddar pojken till livet med en dekokt av örter.

Hesselius rör sig alltså i annorlunda kretsar än brodern i Philadelphia. Han möter de svenskar och finnar som efter förlusten av Nya Sverige lämnades att klara sig själva bäst de månde utan kontakter med hemlandet eller med andra européer, som "utaf Indianernas och Qwakernes omgjänge,... hafwa blifwit så rude". Pehr Kalm relaterade 1748 om dessa, de övergivna kolonisterna, att

som de här hade intet/annat folck at omgås med än de villa indianer, så aftogo de mer och mer i åtbörder från de europaeiska och gamla svenska, och började likna mer och mer indianerne, så at vid engelsmännernes hijtkomst de svenska til en stor del icke voro bättre stort än villa indianer.

Även om det finns överdrifter i denna beskrivning så överensstämmer den med andra källors kommentarer om de svenska och finska kolonister som lämnades efter koloniens fall 1655. Där framställs de som ovårdade, begivna till dryckenskap, och understundom som hotfulla - en karakteristik som också används om indianer.

Att det fanns fog för denna sammankoppling mellan svenskar och indianer visas av de ofta förekommande exemplen på svenskar som agerar som tolkar och medlare mellan andra européer och indianer. Detta gav också svenskarna en möjlighet att framhärda i en betoning av en egen särskild identitet som "svensk nation" och att som medlemmar av denna avstå från att ta ställning i koloniala dispyter.

Historiker och antropologer har alltmer börjat intressera sig för medlarrollen i möten mellan olika kulturer. Medlarna, eller kulturmäklarna kunde vara indianer eller vita som på olika sätt hamnat, eller ställt sig, mellan två (eller flera) kulturer och lärt sig manövrera i båda. De lärde sig hur man tänkte och betedde sig på olika sidor och deras kompetens när det gällde att förstå olika perspektiv gjorde dem oumbärliga för alla sidor, även om långt ifrån alla litade på dem. Den amerikanske historikern Frederick Fausz analyserar tolkar i kolonien Virginia och konstaterar att dessa agerade som mellanhänder men förblev marginella män bland både indianer och vita och drevs i olika riktningar av skiftande politiska vindar. De mest indianlika av dessa tolkar tycks ha överlevt längst i sin roll, men deras engelska landsmän betraktade dem med en blandning av beundran, uppskattning, avsky och misstro.

De svenskar som agerade som tolkar och kontakter mellan holländare/engelsmän och indianer stod förvisso i marginalen av det europeiska samhället i kolonierna, men de var inte de vindflöjlar som Fausz beskriver. De betraktade sig som medlemmar i den "svenska nationen" och framtvingade säravtal med de holländska och engelska administrationerna och såg sig inte alltid nödda att följa koloniala påbud och föreskrifter. Denna särroll förde inte med sig kolonial status, vilket avslöjas i de omdömen som ges om svenskar/finnar, men möjliggjorde under flera decennier en balansakt mellan européer och indianer där de var oumbärliga 
för båda sidor. De svenskar som fortsatte som tolkar då Pennsylvanien grundades blev till slut förhållandevis accepterade i den engelska koloniala strukturen och tog förr eller senare steget över till att fullt ut associera sig med det europeiska samhället. Så finner vi t ex Peter Rambo, Peter Kock och Israel Helm som aktade medlemmar i den koloniala administrationen på början av 1700-talet, trots att de så sent som 1670 vägrat att ta engelsmännens sida i en konflikt med lenaperna. Men en stor andel av de svenskar som slog sig ner längs älvar och tillflöden förblev anonyma och en del flyttade säkert vidare västerut med sina indianska grannar då det engelska trycket ökade österifrån.

I denna miljö är det kanske inte så underligt att den nyfikne Andreas Hesselius "s\&aringg" indianer på ett annat sätt än de flesta av sina samtida vita. Trots att han inte hade någon framgång i missionsarbetet gentemot lenaperna så fortsatte han ett regelbundet umgänge med dem och lärde sig att känsligt notera olika kulturella uttryck.

Medan brodern Gustaf tycks ha tillbringat en större del av sin tid i staden Philadelphia där han också ägde hus, så var Andreas en mer sällsynt besökare. År 1721 reste han dit för att övervara ett möte mellan lenaper, senecaindianer (tillhörande irokesförbundet) och guvernören William Keith. Engelska protokoll finns från många sådana möten, men Hesselius är ensam om en observation som tvingar till funderingar kring konsten att se. Han beskriver välvilligt de indianska hövdingarna som besöker Keith: "bägge hade ett wackert och förnämt ansende, alfwarsamma åtbörder, dock therhos milde och fromme ögon". Så fortsätter han:

En stund therefter kommer Drottningen spatzerandes med sina Wilskor en efter en, men hon distingverades ifrån de andra allenast med ett swart täcke, som hon bar öfwer then ena axlen, war eljest til sin complexion något hwitare $\mathrm{i}$ ansichtet, kanskie thet swarta kläde satte henne så af. Eljest war hon en liten nätt och wälskapad Menniskia, men såg nästan för menlös ut at wara drottning ibland så många fräcka willskor af illsluga ögon.

Denna särskilda entré och närvaro av kvinnorna vid mötet stämmer med antropologisk forskning som visat hur kvinnor som grupp (och även individer) utövade politiskt inflytande vid sidan av männen. Det viktiga arbetet med majsodling leddes i de lenapiska byarna av en äldre kvinna med hög rang. Hennes position innebar också makt över tillsättningen av sachems. Denna ledande ställning var inte beroende av kvinnans relation till någon man utan av hennes position i en släktlinje, vilken för övrigt räknades på mödernet.

\begin{abstract}
"Drottningens" närvaro vid denna förhandling var säkert inte en slump, hon och de andra kvinnorna var heller inte där som bihang till hövdingarna och deras män, utan de representerade den kvinnliga delen av det lenapiska samhället i den viktiga kontakten med de engelska grannarna. Kvinnornas närvaro noteras ibland i förbigående i det officiella provinsiella materialet, men oftast förbigås de med tystnad. Ändå tror jag att Hesselius "sett rätt" och att hans beskrivning ger en mer komplett bild av verkligheten som den utspelade sig i Philadelphia 1721 än vad andra dokument gör. Hesselius kan, liksom andra iakttagare, inte frigöra sig från europeiska föreställningar och består kvinnan med den enda för honom lämpliga titeln "drottning" medan de efterföljande kvinnorna beskrivs ha en vild framtoning. Trots denna värdering av det han ser, noterar Hesselius som en faktisk händelse både kvinnornas självständighet och närvaro i egen rätt. Om denna iakttagelse är han tämligen ensam i den koloniala världen. Säkert saknades inte lenapiska kvinnor vid andra förhandlingar under en stor del av den tidiga europeiska kolonisationen i området, men det är endast Hesselius som gett en så tydlig beskrivning av deras deltagande.
\end{abstract}

Trots att de båda bröderna Hesselius anländer samtidigt till Amerika så hamnar de snabbt i skilda miljöer. Gustaf, kanske som följd av kontakter han fick genom sitt giftermål till Lydia från Nya England, etablerade sig om än inte helt smärtfritt i Philadelphias intellektuella och kulturella elit, medan Andreas levde ett mer kringflackande liv som resande predikant för de spridda svenska församlingarna, ett liv som också gjorde det nödvändigt och försåg honom med möjligheter att lära känna landet och de ursprungliga invånarna. Redan ett par år efter ankomsten skönjs en skillnad i deras beskrivningar av indianerna. Ett exempel till jämförelse ges i deras redogörelser för indiansk förtjusning i Gustafs färger. Gustaf skrev till sin mor att "en af deras Konung" besökt honom och förundrat sig över målarens porträtt:

Jag målte och hans ansichte med röd färg. Han gaf mig för mitt omak ett utterskin och lofwade mig att iag skulle få måhla hans Conterfei och sända till Swerge, - men iag såg honom intet sedan.

Han fortsätter sedan direkt med de ovan citerade negativa omdömena om indianernas levnadsätt.

Andreas berättelse i dagboken antyder att han förmedlat kontakten. En dag i juli medan Andreas "roade" 
sig med att studera persikoträd kom "ett sändige bud til mig ifrån Indianernes Sacheman Capitaine Pockhæls". Hövdingen önskade framställa en förfrågan om att få några färger av Gustaf, i synnerhet cinober, som han ville använda för att måla sitt ansikte med. Denna händelse leder osökt, liksom i Gustafs brev, över i en beskrivning av indianerna som skarpt skiljer sig från broderns. Här finns inga nakna vildar som lever likt svin. I stället refererar hans deras utseende interfolierat med kunskap som han inhämtat från namngivna individer. Dagboksanteckningar och brev är inte helt jämställda i källhänseende. Med denna reservation i minne så framstår det ändå som om Gustaf målar bilden av den "andre" i all sin endimensionella inskränkthet, medan Andreas försöker förmedla bilden av människor han mött och vars kultur han börjar lära känna.

1735, när 21 år gått sedan brevet till modern, målar Gustaf sina porträtt av Lappawinzo och Tishcohan. Något tycks ha hänt. Det som i brevet framstod som en typisk europeisk inställning till indianer, fylld av schabloner, skalas av i porträtten. Inga källor har återfunnits som kan kasta ljus över denna förändring, kanske skall den tillskrivas konstnärens känslighet för intryck och form. Ändå kan det knappast vara en slump: porträtten av lenaperna, orgelbyggandet i Bethlehem under den allra första tiden då denna stad grundades som indianmission och den efterföljande övergången till moraviernas tro. Gustaf stod, liksom sin bror, på gränsen mellan kulturer och denna placering förstärkte hans förmåga att se flerdimensionellt på de indianer han hade framför sitt staffli.

Varför ser Andreas Hesselius det inte andra ser? Man kan till viss del tolka det som ett utslag av ett naturintresse och fascination vid floran och faunan men att söka förklaringen till ett kulturellt djupseende i förhållande till indianer i ett naturintresse riskerar att vrida oss mot en annan schablon, nämligen den som i indianen sett den ädle vilden som i allt levt i samspråk med sin omgivning. Det Andreas Hesselius och hans indianska bekanta sysslade med var inte friluftsliv, att gå i skog och mark och lära känna floran och faunan var inte enbart en hobby, han provade inte indiansk mat av kulinarisk nyfikenhet, betygsatte inte förtäring och miljö för turister. Prästerna i Nya Sverige-området var för det mesta tvungna att livnära sig själva då församlingarna varken kunde eller tycks ha velat försörja sina själasörjare. Skillnaden mellan Hesselius och andra präster var inte att han fann sin utkomst i jakt och samlande, eller att han nödgades lära sig av indianer hur man tillredde vissa rätter, utan skillnaden synes vara den att han njöt av att göra det. I så måtto ligger förklaringen i hans personlighet. Marginalpositionen som svenskarna i nya världen hamnade i var för honom inte en tvångströja utan en möjlighet.

Men denna position i marginalen utgör den struktur i vilken Hesselius hamnade och det andra benet i analysen av hans agerande. Marginalen kan betraktas som placerad i utkanten av något, i detta fallet ett samhälle, men den kan också befinna sig i skärningspunkten mellan två kulturer. Då är marginalen plötsligt lokaliserad i mitten, centralt placerad för att kunna ha överblick åt flera håll. Den som befinner sig på marginalen, d v s inte är fullt ut integrerad i någon kultur, har möjlighet att röra sig emellan båda och utveckla de färdigheter och kunskaper som är nödvändiga för att medla mellan kulturer. Detta gjorde många svenska och finska kolonister kring Delawarefloden och här placerade sig Andreas Hesselius.

Gustaf Hesselius efterlämnade ord visar inte, till skillnad från broderns, på något personligt intresse för andra kulturer och miljöer. Men hans målningar och flertaliga religionsbyten avslöjar en position och utgångspunkt som skiljer honom från den kulturella miljö i Philadelphia till vilken han ansågs höra. Gustaf befann sig i dess marginal. Familjen Penns önskan om porträtt av både engelska och indianska ledare gav här Hesselius ett tillfälle att betrakta från marginalen. Resultatet blev, vare sig det var medvetet eller ej, de realistiska porträtteringar som mer än något avslöjar bröderna Penns svekfulla indianpolitik för vad den var.

Konsten att se flerdimensionellt när det gäller den egna och andra kulturer växer alltså fram ur två förutsättningar. Å ena sidan finns en strukturell förklaring i den marginalisering som möjliggjort den mellanposition som svenskar/finnar befann sig i och den gemensamma gränskultur som delades av nybyggare och indianer. Å andra sidan må förklaringar sökas i det personliga intresset. Andreas nyfikenhet att iaktta, lära sig och förstå det nya, hans öppenhet för det oväntade i kontakten med indianer gjorde det möjligt för honom att dra nytta av den svensk/finsk/indianska strukturen. Gustafs vacklande vandring mellan europeiska kulturer och religiösa riktningar öppnade också för ett fördjupat seende. Ur dessa konstellationer växte både de förunderliga porträtten av Lappawinzo och Tishcohan och de inträngande beskrivningarna av Pennsylvaniens människor och natur. 
etyder. En vänbok till Stellan Dahlgren', Uppsala, 1997: sid 83-94.) 